\title{
Aims, Goals, and Objectives
}

\section{Nel Noddings}

Stanford University

\section{ABSTRACT}

Aims, goals, and objectives can be thought of as hierarchically ordered educational purposes. In today's policy discussions, aims (the most generally stated purposes) are too often sacrificed for specific learning objectives. Although aims, unlike objectives, cannot be pursued and measured directly, their continued discussion is essential; careful consideration of aims should guide our choices of curriculum and pedagogy and the selection and evaluation of goals and objectives.

Key words: aims, goals, objectives, democratic education

\section{RESUMEN}

Los fines, las metas y los objetivos pueden pensarse como propósitos educativos jerárquicamente ordenados. En las actuales discusiones políticas, los fines más generales, son sacrificados demasiado a menudo por objetivos de aprendizaje más específicos. Aunque los fines, a diferencia de lo que sucede con los objetivos, no se pueden perseguir ni medir directamente, su discusión continua resulta esencial. La consideración cuidadosa de las finalidades educativas debe guiar nuestra elección curricular y pedagógica, así como la selección y evaluación de metas y objetivos más específicos.

Descriptores: fines, metas, objetivos, educación democrática

\section{RÉSUMÉ}

Les visées, les buts et les objectifs peuvent être conçus comme des desseins éducatifs les plus hiérarchiquement ordonnés. Dans les discussions politiques d'aujourd'hui, les visées (les plus généralement énoncées) sont trop souvent sacrifiées aux objectifs spécifiques du savoir. Quoique les visées, contrairement aux objectifs, ne puissent pas être poursuivies et mesurées directement, la discussion soutenue à leur sujet est essentielle; la considération attentive des visées devrait guider notre choix de programme et de pédagogie ainsi que notre évaluation des buts et des objectifs.

Mots-clés: visées, buts, objectifs, éducation démocratique

$\mathrm{E}$ Ducational theorists usually think of aims, goals, and objectives, in descending order of generality, as statements of educational purpose (Schubert, 1986). In the United States today, unfortunately, these categories have been collapsed into one nebulous clump called "standards". It would take volumes to do justice to the topic of educational purposes. In this brief paper, I want to remind readers of the importance of the three categories and continued discussion of them and, in particular, I want to 
suggest an especially significant role for them in an era of accountability and emphasis on assessment. The particular names we use for the categories are not so important. What matters is the underlying structure - the nature of the categories themselves and how they are related.

Aims and goals are often brushed aside in favor of objectives, because the first two are "vague" and the last can be cast in language conducive to measurement. But the very vagueness of statements of aims and goals can be an advantage. It invites "aimstalk" (Noddings, 2003), and that discussion is essential to a value-laden enterprise such as education. Further, I will argue that we need to assess not only specific student outcomes but also what we as educators are doing, what we offer, and why. Thus, aims can be used to reflect upon and evaluate our goals. Are the goals compatible with our stated aims or at odds with them? Similarly, goals can be used to evaluate objectives. Is it likely that meeting the suggested objectives for student learning will actually satisfy our stated goals?

\section{Setting the Stage}

Consider two aims almost universally posited by educators in democratic societies: 1 ) to prepare students for democratic life; 2) to prepare citizens who are literate. Notice that these aims reflect interest in the welfare of both individual students and the society to which schools are responsible. It is characteristic of aims - as broadly stated educational purposes - that they reflect the values of the society served by the schools, and they are designed to establish and maintain the society's ideals.

But notice also that such aims are not easily measured. How do we know when students are prepared for democratic life? It may seem easier at first to judge if citizens are literate, but even this aim is vague, and it must be filled out differently as times and technology change.

To "fill out" an aim, we establish goals thought likely to promote the aim. Goals are usually established for grade levels and/or particular subject matters. With respect to the literacy aim, for example, mathematics departments may construct a goal of mathematical literacy, and a school may decide that a suitable sub-goal for fifth grade mathematics is the understanding of fractions. I'll return to this example a bit later, and we will see that it calls for substantial thinking and discussion. It is more specific than the larger goal of mathematical literacy and the aim of general literacy it is meant to serve, but it is still somewhat vague. What do we mean by "understand"?

The next step is to construct objectives that define the meaning of understanding. Exactly what do we expect by way of student outcomes? At this stage, we usually write our objectives in terms of measurable student outcomes. But, as we will see, there is still the need to say what teachers will do to accomplish the objectives. Some methods chosen may advance the larger goal and some may not. Aims are used not only to derive goals and objectives but also to evaluate them. Today, when so many objectives seem to pop up with little justification, it is especially important to evaluate them in the light of accepted aims. In what follows, I will describe this process in more detail. 


\section{Aims}

As purposes stated at the highest level of generality, aims remind us of our ideals and direct the construction of goals and objectives. Some policymakers today insist that there is no need to discuss aims, because we already know what we are trying to accomplish in schooling, and we should simply get on with it. Robert Maynard Hutchins (1999) and other "perennialists" argued years ago that the aims of education are fixed universally for all time, but few of us believe that now when we live in an age of rapid change.

However, even if we believed that educational aims are, at some level of generality, fixed and universal, we would still need to discuss them in the process of constructing goals and objectives. Consider the first aim mentioned above: To prepare students for democratic life. How might this aim guide us in making educational choices?

Quite often a familiar mistake is made at the outset. We ask what part of the curriculum is most closely aligned with this aim. Where, in the context of the standard curriculum, should we place the responsibility for preparing students for democratic life? Our usual answer is "social studies." Although I think this answer is misguided, it does invite immediate debate, and some educators will insist that the proper answer is not "social studies" but history. Those who respond this way must show that the study of history better prepares students for democratic life than social studies.

This debate may be useful, but at bottom, it is a distraction. At best, the debate induces a critical examination of current practice. If educators believe that social studies (or history) is the subject best suited to preparing students for democratic life, why have they permitted that subject to be neglected in favor of intensive instruction in mathematics and reading? A consideration of aims can lead us to reflect on our current curricular choices.

As I suggested earlier, however, this approach to the discussion of aims may be misguided. It supposes that every educational aim can be pursued through assignment to a particular subject in the traditional curriculum. In aiming to prepare students for democratic life, we should think more broadly. All teachers, not just social studies teachers, should ask how they can contribute to this task. Class meetings, peer tutoring, group work, and participation in deciding the rules of classroom conduct can be used in every subject matter classroom.

Further, in discussing this aim, we should analyze not only curriculum but all of the activities sponsored by schools. For instance, the tendency today, in heedless pursuit of higher test scores, is to cut back on extra-curricular activities and concentrate more heavily on academics. However, it is in class meetings and various club activities that students have real opportunities to practice what they have learned about democratic processes. If we are serious about preparing students for democratic life, we will not reduce these activities. We might indeed give them more attention and monitor them closely to be sure they are serving the intended purpose (Noddings, 2007).

One significant function of aims-talk is to challenge our seriousness of purpose. Critical theorists, among others, urge us to engage in such discussion. Do our statements of aims exemplify a real commitment to well-considered ideals, or do they mark us as hypocrites? Almost every school gives lip-service to an aim of critical thinking, for example, but the same schools often discourage or even forbid critical discussion of 
controversial issues. Can critical thinking be learned without exposure to controversial issues? (Noddings, 2006; Spring, 1997). Are there times when such discussion should rightly be limited because it might impede the pursuit of other legitimate aims? These are important questions for educators to consider.

In the United States today, critics have charged advocates of the federal No Child Left Behind act with hypocrisy. Do advocates of the law honestly want to improve the educational opportunities of poor and minority students, or do they really want to leave many children behind? (Meier \& Woods, 2004). Do they want to improve or to destroy public education? (Kohn, 2004).

It may well be that supporters of NCLB sincerely want to improve the conditions of public schooling for all children. When results appear opposite to stated purposes, however, something is wrong. Not only should there be thorough analysis of the stated aims but, in addition, there should be lively debate over the means chosen to pursue the aims. The first step in that debate should be to ask how the aims will be translated into goals.

\section{Goals}

Usually the translation from aims to goals is made in the context of subject matter disciplines - in mathematics, language, science, and other subjects. However, careful discussion at the level of aims might raise questions about the centuries-old organization of curriculum around the disciplines. Perhaps that is not the best structure for the 21 st century. The biologist, Edward O. Wilson, has suggested de-emphasizing the disciplines:

Given the convergence and blending of disciplines, the best approach to general education in the future would seem to be less discipline-oriented and more problem-centered.... Such an approach would require some breadth on the part of the instructor, or at least team-teaching by a group of complementary experts. (2006, pp. 136-137)

Although I agree enthusiastically with Wilson, I also believe it is unlikely that schools will move away soon from the discipline-based structure they now use. We can, however, keep an interdisciplinary aim in mind as we ask how to translate aims into goals at the level of school subjects. We can try to broaden the disciplines from within.

All teachers should consider what they can do to advance the school's general aims. Math teachers should be concerned with general literacy as well as mathematical literacy; similarly, they should be concerned with educating their students for democratic citizenship. How can math teachers help to produce democratic citizens? One thing they can do is to make it clear that they respect the full range of human talents and interests. Many highly intelligent, creative people have difficulty with mathematics. When math teachers express their appreciation of non-mathematical talents and their gratitude for the variety of work on which our society depends, students are likely to increase their own appreciation for workers at every level, and such appreciation is fundamental to democracy. 
Math teachers might formulate goals compatible with more general aims - for example: to introduce students to the uses of mathematics in a wide range of natural and social sciences; to share with students biographies of great mathematicians - particularly those whose interests have gone well beyond mathematics; to provide choices for students in selecting projects and on the level of problems they will complete to satisfy requirements; to encourage appreciation for the connection of math to art and music; to encourage cooperative problem solving.

The aim to educate mathematically literate citizens might induce another set of goals and also provide endorsement of those just mentioned. What does it mean to be "mathematically literate"? This question should invite a lively discussion in math departments. Certainly, mathematically literate citizens should have command of the fundamental processes, but they should also be able to understand common statistical terms such as mean, median, and margin of error. They should acquire a mathematical vocabulary that signifies knowledge of what various subtopics are about, even if they do not achieve mastery of those fields. They should know, for example, that "calculus" has to do with variation - rates of change, motion, areas, and volumes - and is indispensable in physics and engineering. A serious, on-going discussion of mathematical literacy could help math teachers to separate important topics from trivial ones. We might question, for example, why we persist in teaching courses in Euclidean geometry, especially in a way that has become popular in the United States - with little or no work on proofs. Are the "facts" of Euclidean geometry worth learning? Why? Can one be mathematically literate with no understanding or appreciation of the concept of proof?

To engage in such discussion profitably, math teachers need much broader preparation than other math majors, but it has been hard to convince university professors of this. Too often, professors and policymakers insist that math teachers should have exactly the same training as other math majors. The reasons for this odd recommendation usually point to status. It is believed that, if teachers pass the same courses as other math majors, the public will have to acknowledge that teachers are smart, that they are "just as good" as engineers and economists. This sort of thinking does not facilitate the production of teachers who have the broad knowledge required of teachers in the 21 st century. Instead of looking carefully at the educational aims that teachers are expected to promote, we allow ourselves to be distracted by issues of status.

Before moving on to a discussion of objectives, it is worth returning briefly to the relation of aims to goals. Some credible thinkers today suggest that the entire structure of aims for 21 st century education should be analyzed and revised. If this is done (and I think it should be done), and if despite this revised thinking, the present organization of curriculum around the disciplines is retained, what goals should mathematics educators establish to contribute to aims such as the following: to educate students who can communicate effectively; who work well as members of teams; who are flexible in the face of change; who are skilled in analysis and conceptualization? Most mathematics teachers are not prepared to think productively along these lines.

I have used mathematics as a continuing example, but it should be clear that one might substitute any other discipline and retain the broad outline of my argument. 


\section{Objectives}

Teachers today are encouraged (sometimes commanded) to have a learning objective for every lesson. Often these objectives are simply drawn from a textbook or list of "standards." Teachers are rarely asked to relate their objectives to goals and aims. Objectives frequently take the following form:

On a paper and pencil test, students will add fractions with different denominators up to 12 , with at least $80 \%$ accuracy.

How should teachers think about such an objective? Ideally, they should think first how the objective fits with larger goals and aims; then they should do a task analysis and identify the skills required to achieve the objective. One relevant larger aim is to achieve literacy - in this case, mathematical literacy, and the goal is to understand fractions.

The teacher's job is not only to teach children how to add fractions but also to do it in such a way that the larger aim and goal are advanced. Suppose students are asked to add $5 / 6$ and $3 / 8$. They must find a common denominator. When I was in elementary school, we were taught to work this way: Consider the larger denominator, in this case, 8. Will 6 "go into" 8 (that is, will 6 divide into 8 without remainder)? If not, try $2 \times 8$; if that doesn't work, try $3 \times 8$, etc. Since $3 \times 8=24$, and $6 \times 4=24$, we can conclude that 24 is the lowest common denominator. This method is quick and easy, and it works for most of the fractions found in elementary textbooks. But it does not contribute much to the understanding of fractions or to mathematical literacy.

A better approach is to factor both denominators: $6=2 \times 3$ and $8=2 \times 2 \times 2$. In doing this, we spend some time talking about the Fundamental Theorem of Arithmetic: Every integer is either prime or can be expressed uniquely as the product of primes. Now we notice that the lowest denominator must include every prime that occurs in either denominator, and the L.C.D. $=2 \times 2 \times 2 \times 3=24$. This method takes more time and requires more discussion, but it takes into account the aim of mathematical literacy. It is also the method that will be required in adding algebraic fractions, and so it is very important for the students' mathematical development.

The method requires teachers to review (or teach) the concept of prime numbers and to introduce the Sieve of Eratosthenes to test for primeness. With sufficient practice and discussion, students may discover how far they need to test to be sure a given number is prime. Clearly, this sort of exercise adds to mathematical literacy; yet there are still texts that just concentrate on adding two fractions and neglect the far more interesting concepts involved in performing this task.

Notice, too, that the preferred method encourages questions, such as why we need the three 2's in 8 but do not have to add a fourth because of the 2 in 6 . Teachers can say, Well, let's see what happens if we use four 2's. Indeed, we discover a simple way to get a common denominator, 48 (just multiply the two denominators), but it is not the lowest common denominator. Does this matter? It really doesn't unless you are asked to express your answer in "simplest terms," but it may save arduous computation in some cases. Time can profitably be spent working both ways and reminding students how to work with equivalent fractions. 
If this were a chapter in a math methods book, I would spend a whole chapter (at least) on the topic, giving much time to fractions as rational numbers and locating them on number lines. (Yet many texts do not approach the topic this way, and teachers remain poorly prepared to promote mathematical literacy.) In this paper, however, our purpose is to show how important it is to connect aims, goals, and objectives. The teacher's first question should be, Why am I teaching this? and then, What methods will best help us to meet not only the immediate objective but also the aims and goals it is meant to serve?

\section{Planning, Analyzing, Reflecting}

Thoughtful people have always raised objections to established patterns of education. Indeed some of the world's most creative thinkers have been highly critical of their own schooling. George Orwell, for example, wrote:

You forget your Latin and Greek within a few months of leaving school - I studied Greek for eight or ten years, and now, at thirty-three, I cannot even repeat the Greek alphabet - but your snobbishness, unless you persistently root it out like the bindweed it is, sticks by you till your grave. (1958, p. 137)

Orwell is, at one and the same time, deploring the useless drudgery of his course work and acknowledging the enormous power of schooling to preserve class distinctions. Educators before and during Orwell's school years did debate the aims of education, and much of what they did was vigorously, if mistakenly, defended. It was thought, for example, that the study of mathematics and Latin somehow strengthened the mind. This idea is now largely discredited and Latin has been virtually abandoned, but mathematics is still argued to be essential. The question for today's educators - one rarely asked - is why mathematics is held to be essential. And, then, which mathematical topics are essential for everyone? Which topics are essential only for those planning careers that regularly use mathematics?

In the early 20th century, Alfred North Whitehead warned about the dangers of "'inert ideas' - that is to say, ideas that are merely received into the mind without being utilized, or tested, or thrown into fresh combinations" $(1967$, p. 1). Whitehead pointed out that fresh, even revolutionary, ideas, tend to deteriorate into inert ideas. Ideas that are exciting to one generation and to its teachers become formalized, routinized, and dull to the next generation. Because the aim seemed obvious at one point, educators in succeeding generations forget to ask why they are teaching certain material and whether their methods are enhancing or defeating their present aims.

As Orwell and many other writers have argued, the implicit aim of traditional, liberal arts education has been to separate the classes and maintain the status of elites. On this aim, education all over the world has been highly successful. There are those in the United States who have insisted that, "We are politically a classless society. Our citizenry as a whole is our ruling class. We should, therefore, be an educationally classless society" (Adler, 1982). Others regard the claim that we are a classless society as 
demonstrably untrue (see, for example, Apple, 1996), but belief that it is true or that it could easily be made true lies at the heart of today's reform movement.

Even if we agree that our societies are, or should be, classless, we may disagree strongly on appropriate approaches to education. Most reformers today, in the tradition of Horace Mann, want to remove class distinctions by providing the same education for all students. Some politicians and policymakers even insist that all students should go to college. In dramatic contrast, Orwell wanted people to recognize the essential contributions and admirable strengths of the working class. Most hard-working people in the middle class - barely able to make ends meet - might do better as solid members of the working class, Orwell argued: "for, after all, we have nothing to lose but our aitches" (1958, p. 232).

There are important points to consider on both sides of this argument. It seems right that all children should have the opportunity to prepare for college if they wish to do so. But, in contrast, it also seems right to provide a variety of fine programs that recognize substantial differences in the interests and talents of individuals. If we coerce all children to take college preparatory courses, we put at risk the great promise of democratic education. We implicitly demean the work and intelligence of our working class. On the one hand, we must avoid "relegating" or "dooming" children to inferior courses poorly designed to prepare them for the world of work. On the other, we must recognize that forcing children into studies they hate may kill their interest in learning and destroy their self-confidence. Further, many admirable aims of education do not concentrate on economic life but on life more fully construed.

These are enormously complicated issues and deserve widespread, critical discussion. By analyzing educational aims, we may discover that it is possible to address many of them in vocational and commercial courses as well as in traditional academic courses. That project begins with the sort of respect and appreciation urged by Orwell. But, through such analysis, we may also question what we do in our college preparatory courses. Does the study of traditional liberal arts best prepare students for full and satisfying lives? Why do we persist in requiring Euclidean geometry? Why do we construct our reading lists around great writers instead of great themes or existential questions? Why do we insist on "real" science that emphasizes abstract principles and vocabulary and neglect the "popular" science that addresses real-life problems and on which the vast majority of intelligent nonscientists depend for a lifetime of information?

Analysis should lead us to challenge statements such as that by Mortimer Adler: "The shape of the best education for the best is not unknown to us" (1982, p. 7). If that "best education" was implicitly designed to create and maintain an elite and not to prepare for a happy and moral life, then it hardly makes sense to force it on everyone. We must reflect on the aims of traditional liberal education to be sure that they are morally and democratically justified. They may need to be revised or supplemented. Moreover, we might find that the finest of these aims may be successfully pursued through different subject matters.

Reasonable people might also challenge on economic grounds the present demand that everyone go to college. It is true that, on average, a college graduate makes considerably more money over a lifetime than one who does not go to college. However, if we 
were to succeed in getting everyone to college, the average wage of college graduates would surely go down - perhaps dramatically. Then most of us would join the working class as suggested by Orwell, but not by choice. And who would then do the necessary work that is now done by those without a college education? These issues should be brought into the open and discussed vigorously.

The fundamental premise of democratic life is the belief that all competent citizens can participate in political decision-making. A value that supports this belief is a hearty respect for all forms of honest and necessary work. Instead of converting all people into members of the educational elite, we might do better to make the lives of everyone full and satisfying. To achieve this democratically essential state, we must expand the discussion of educational aims and engage endlessly in planning, analyzing, and reflecting.

\section{References}

Adler, Mortimer J. (1982). The paideia proposal. New York: Macmillan.

Apple, Michael W. (1996). Cultural politics and education. New York: Teachers College Press.

Hutchins, Robert Maynard. (1999). The higher learning in America. New Haven: Yale University Press. (Original work published 1936)

Kohn, Alfie. (2004). Test today, privatize tomorrow: Using accountability to "reform" public schools to death. Phi Delta Kappan, April, 569-577.

Meier, Deborah \& Wood, George (Eds.). (2004). Many children left behind. Boston: Beacon Press.

Noddings, Nel. (2003). Happiness and education. Cambridge: Cambridge University Press.

Noddings, Nel. (2006). Critical lessons: What our schools should teach. New York: Cambridge University Press.

Noddings, Nel. (2007). When school reform goes wrong. New York: Teachers College Press.

Orwell, George. (1958). The road to Wigan pier. San Diego: Harcourt. (Original work published 1937)

Schubert, William H. (1986). Curriculum: Perspective, paradigm, and possibility. New York: Macmillan.

Spring, Joel. (1997). Political agendas for education. Mahwah, NJ: Lawrence Erlbaum.

Whitehead, Alfred North. (1967). The aims of education. New York: Free Press.

(Original work published 1929)

Wilson, Edward O. (2006). The creation: An appeal to save life on earth. New York: W. W. Norton. 
16 Encounters/Encuentros/Rencontres 